\title{
Oral Verrucopapillary Lesions: A Diagnostic Conundrum
}

\author{
Lavanya $\mathrm{A}^{1}$, Sowmya SV ${ }^{2}$, Roopa S Rao ${ }^{3}$, Dominic Augustine ${ }^{4}$, Vanishri C Haragannavar ${ }^{5}$
}

\begin{abstract}
Aim: This review provides an overview of various classifications and aims to focus on the characteristic distinguishing features of oral verrucopapillary lesions that direct towards arriving at a diagnosis and assessment of their biologic behavior.

Background: A variety of pathological conditions affect the normal morphologic and surface characteristics of the oral mucosa. Verrucopapillary lesions (VPLs) are one such group of diseases that are diagnostically disputed and comprise of a spectrum of reactive, benign and malignant lesions. They can be categorized broadly into focal and multifocal lesions.

Review results: The classic clinical, histopathological and Immunohistochemical characteristics of oral verrucopapillary lesions may help in their accurate diagnosis.

Clinical significance: Despite, few indistinguishable clinical presentations of VPLs, their specific morphology, etiology, and discrete histopathological features may ease out the diagnostic dilemma and facilitate appropriate treatment.

Keywords: Biologic behavior, Oral cavity, Verrucopapillary.

World Journal of Dentistry, (2019): 10.5005/jp-journals-10015-1624
\end{abstract}

\section{INTRODUCTION}

B enign, potentially malignant and malignant disorders of the oral cavity affect the normal morphology and stability of the mucosa manifesting as surface alterations. Such alterations can be appreciated as ulcerative, vesiculobullous or papillary/ papular/ polypoid lesions., ${ }^{1,2}$

Verrucopapillary lesions (VPLs) present themselves in varied clinical forms as papillary lesions exhibiting pointed or blunt fingerlike projections, papular lesions featuring small sessile elevations and polypoid lesions with larger, pedunculated, exophytic growths that share similar histopathological features with subtle differences leading to diagnostic dilemma., ${ }^{1,2}$ Some normal oral mucosal structures present on the dorsum of the tongue, may share microscopic appearances similar to verrucopapillary lesions. Filiform, fungiform and circumvallate papillae are such structures showing parakeratinized surface projections microscopically. ${ }^{3}$ But, their diagnosis is of paramount importance as they include a wide spectrum of lesions that range from normal, benign, potentially malignant to malignant which drastically affect the treatment perspective. Hence, this review focuses on the characteristic
1-5 Department of Oral Pathology and Microbiology, Faculty of Dental Sciences, MS Ramaiah University of Applied Sciences, Bengaluru, Karnataka, India

Corresponding Author: Lavanya A, Department of Oral Pathology and Microbiology, Faculty of Dental Sciences, MS Ramaiah University of Applied Sciences, Bengaluru, Karnataka, India, e-mail: drlavsmdsop92@gmail.com

How to cite this article: Lavanya A, Sowmya SV, Rao RS, Augustine D, Haragannavar VC. Oral Verrucopapillary Lesions: A Diagnostic Conundrum. World J Dent 2019;10(2):158-164.

Source of support: Nil

Conflict of interest: None

features of oral VPLs that provide direction in their diagnosis and assessment of their biologic nature..$^{1-3}$

\section{Classification}

- Based on the number and appearance of the lesion (Eversole and Papanicolaou in 1983) ${ }^{1}$ (Flow chart 1).

Flow chart 1: Classification of VPLs based on the number and appearance of lesions (Eversole and Papanicolaou, 1983)

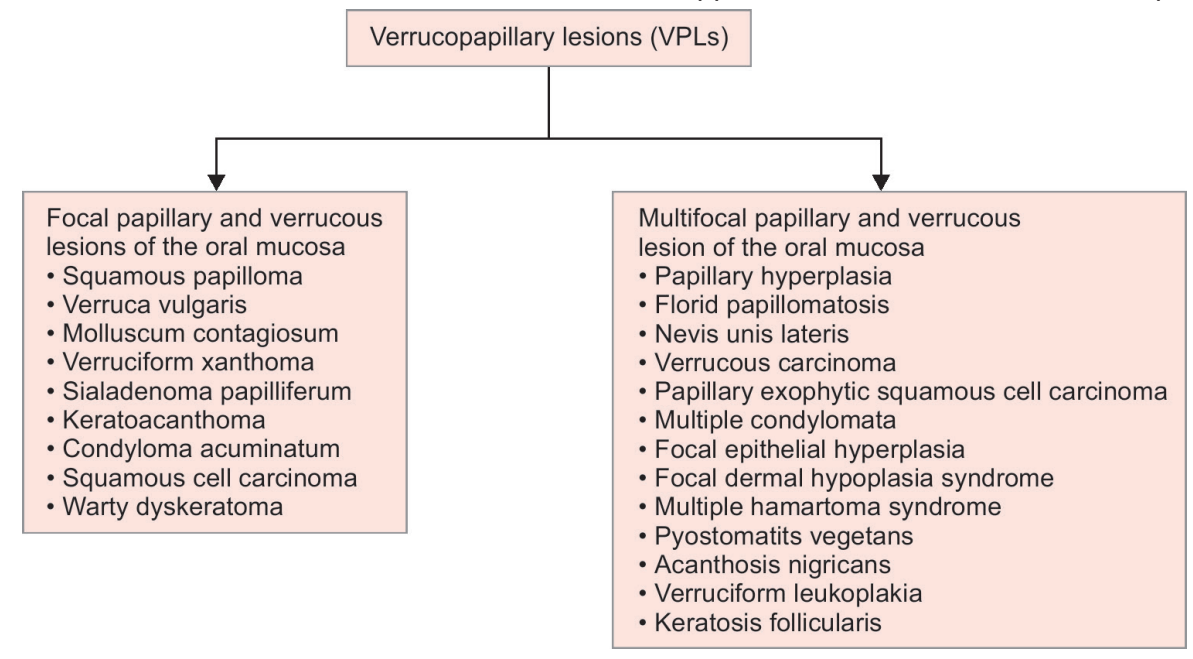

() The Author(s). 2019 Open Access This article is distributed under the terms of the Creative Commons Attribution 4.0 International License (https://creativecommons. org/licenses/by-nc/4.0/), which permits unrestricted use, distribution, and non-commercial reproduction in any medium, provided you give appropriate credit to the original author(s) and the source, provide a link to the Creative Commons license, and indicate if changes were made. The Creative Commons Public Domain Dedication waiver (http://creativecommons.org/publicdomain/zero/1.0/) applies to the data made available in this article, unless otherwise stated. 
- Based on the involvement of HPV as an etiologic factor (Eversole in 2000) $)^{1}$ (Flow chart 2).

- Based on the type of the lesion (Regezi et al. 2003) $)^{3}$ (Flow chart 3)

- Based on malignant potential of the lesion (Thomas and Barret 2009) ${ }^{1}$ (Flow chart 4)

- Based on the growth pattern (working classification) (Flow chart5)

\section{Verrucopapillary Lesions (VPLs) of the Oral Cavity}

The commonly presenting oral verrucopapillary lesions may be broadly categorized into two groups, focal-squamous papilloma, verruca vulgaris, verruciform xanthoma, keratoacanthoma, warty dyskeratosis, and squamous cell carcinoma and multifocal lesions-verrucous carcinoma, papillary exophytic squamous cell carcinoma, focal epithelial hyperplasia, verruciform leukoplakia. ${ }^{1}$

\section{Differential Diagnosis}

In this section, an attempt has been made to discuss some of the common VPLs that have oral manifestations and a wide range of differential diagnosis on the basis of involvement of the lesion.

\section{Focal Papillary Lesions}

Localized papillary growths are depicted by non-viral and viral epithelial proliferations that may be sessile or pedunculated. These lesions show normal coloring while others are white along with

Flow chart 2: Classification of VPLs based on the involvement of HPV as an etiological factor (Eversole, 2000)

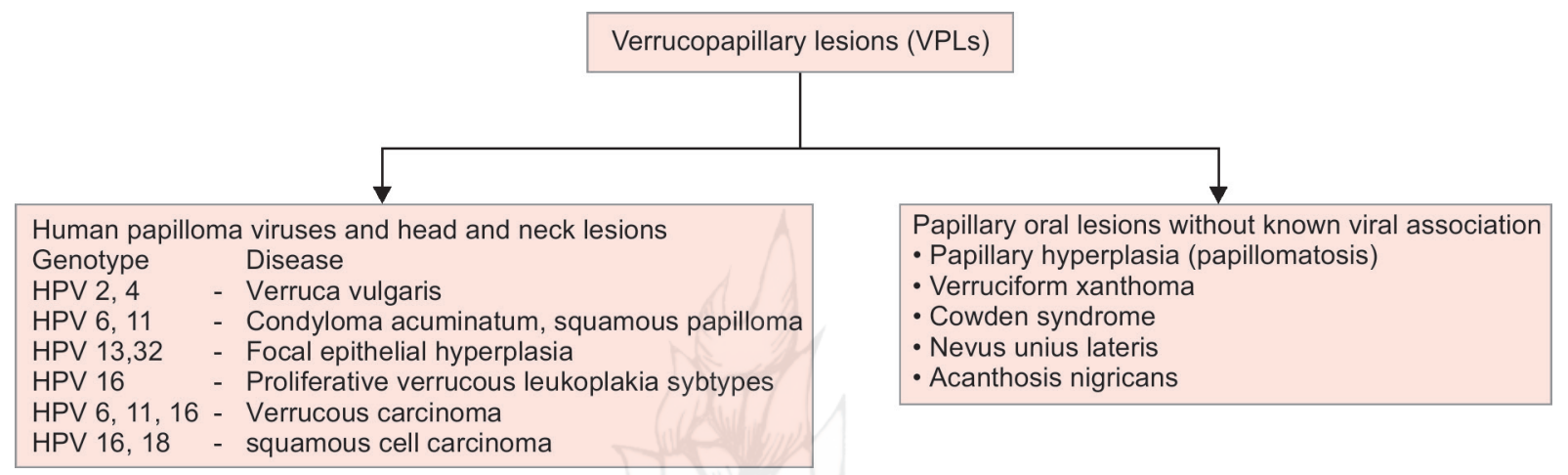

Flow chart 3: Classification of VPLs based on the type of the lesion (Regezi et al, 2003)

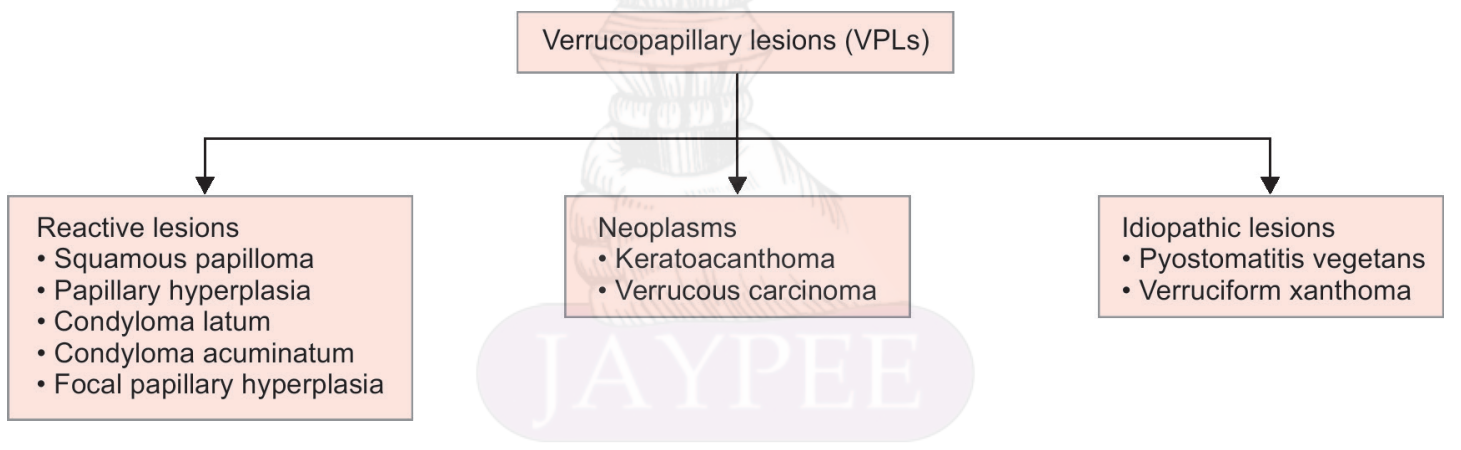

Flow chart 4: Classification of VPLs based on the malignant potential (Thomas and Barret, 2009)

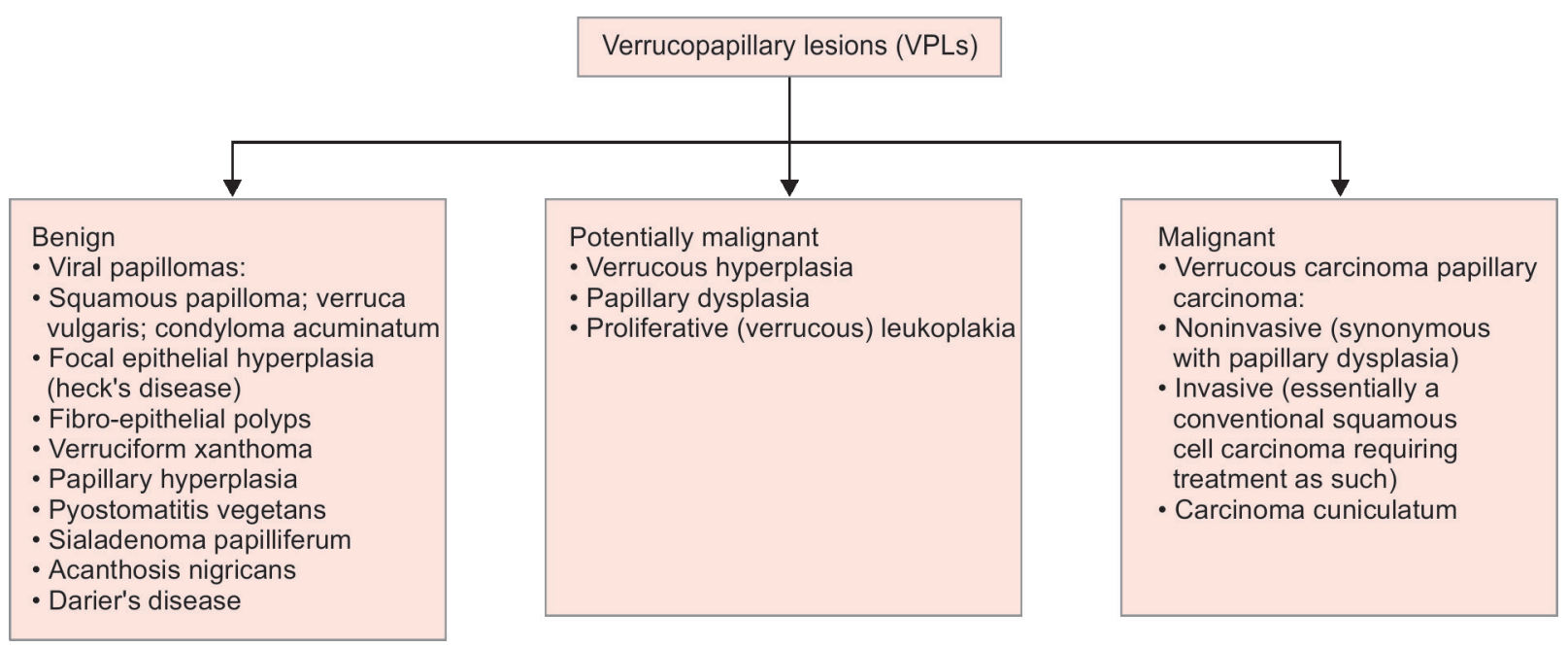


Flow chart 5: Classification of VPLs based on growth pattern of oral VPLs ( working classification)

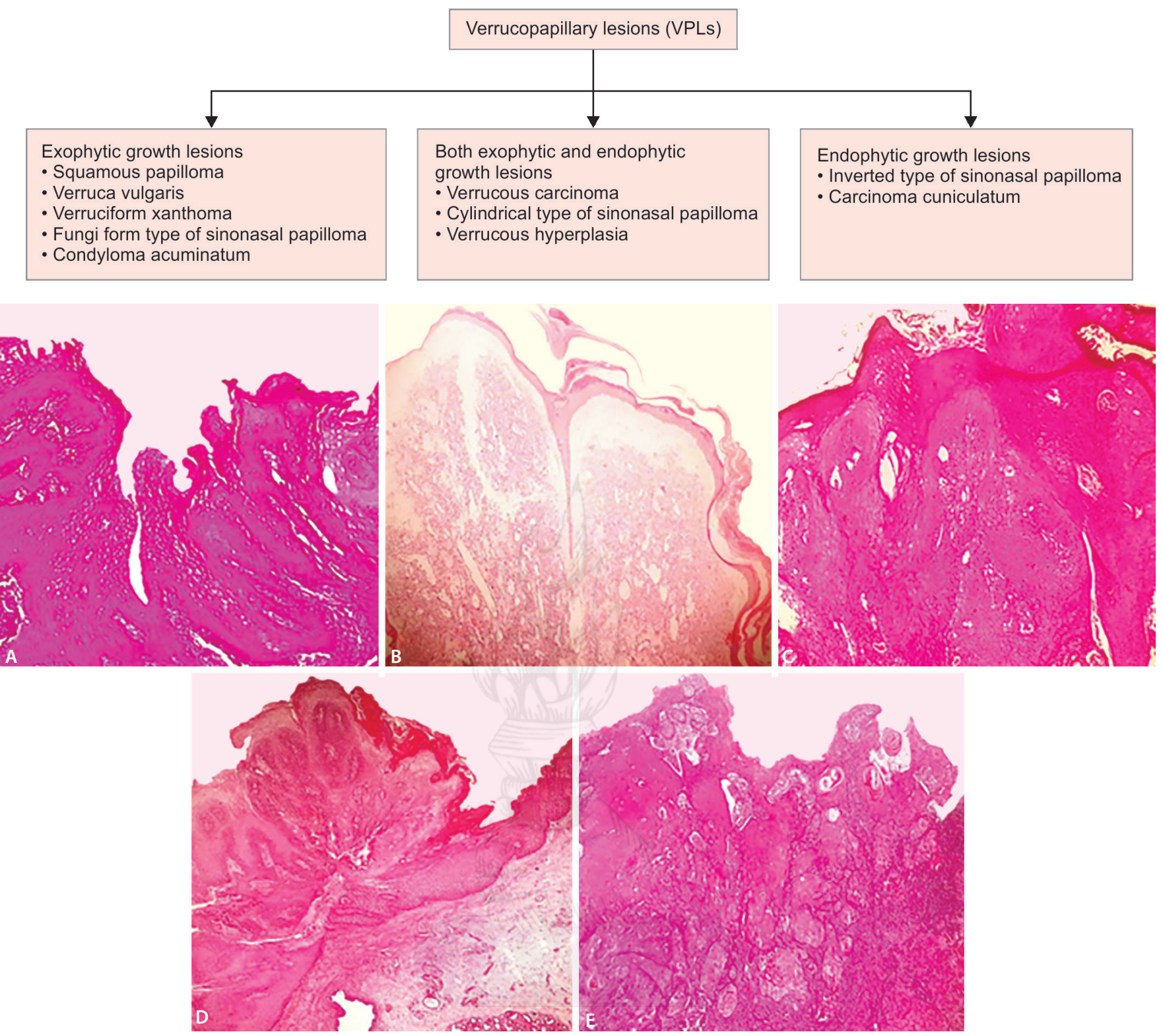

Figs $1 A$ to E: Photomicrographs of (A) Squamous papilloma (H \& E; X100); (B) Keratoacanthoma (H \& E; X100); (C) Verrucous hyperplasia (H \& E; X100); (D) Verrucous carcinoma (H \& E; X100); (E) Papillary Squamous cell carcinoma (H \& E; X100).

rolled margins and distinct collarette. This yields a crateriform or umbilicated appearance. However clinically, these crateriform nodules are not always peculiarized by verrucous or papillary appearance, but histopathological features reveal the acanthotic in folding with keratin crypts. The common focal papillary lesions include squamous papilloma, verruca vulgaris, verruciform xanthoma, keratoacanthoma, warty dyskeratosis, and squamous cell carcinoma. ${ }^{1,3-6}$

\section{Oral Squamous Papilloma (OSP) (Fig. 1)}

Oral squamous papilloma (OSP) is a benign epithelial neoplasm represented as a papillary (or) verruciform mucosal mass which accounts for $3-45 \%$ of all biopsied lesions. This exophytic growth is due to the benign proliferation of the stratified squamous epithelium (Table 1). ${ }^{1,2}$

\section{Verruca Vulgaris}

Verruca vulgaris is also represented as "common wart". It is a persistent lesion of the skin and mucous membrane caused by HPV-2, 4 and 40. It shows benign epidermal proliferation with rare malignant transformation. It is estimated to occur in approximately $7 \%$ of the population. It is a contagious disorder and transmitted to the other areas of the body if left untreated (Tables 1 and 2). ${ }^{7,8}$

\section{Verruciform Xanthoma}

Verruciform xanthoma is a benign mucocutaneous lesion showing papillary-like growth pattern frequently involving oral mucosa. The incidence rate is $0.025-0.05 \%$. It usually presents as a verrucous pattern and in some conditions, may show polypoid, sessile or papillomatous appearance (Table 3). 
Table 1: Differential diagnosis of oral squamous papilloma

\begin{tabular}{|c|c|c|c|c|c|}
\hline Criteria & Squamous papilloma $a^{4-6}$ & Verruciform xanthoma ${ }^{7}$ & Verruca vulgaris 8,9 & Heck's disease $e^{4,5}$ & $\begin{array}{l}\text { Pyogenic } \\
\text { granuloma }\end{array}$ \\
\hline Common site & $\begin{array}{l}\text { Soft palate, tongue, } \\
\text { and lip }\end{array}$ & $\begin{array}{l}\text { Alveolar ridge and } \\
\text { gingiva }\end{array}$ & $\begin{array}{l}\text { Anterior tongue, } \\
\text { vermilion border, } \\
\text { and labial mucosa }\end{array}$ & $\begin{array}{l}\text { Labial, buccal } \\
\text { and lingual }\end{array}$ & $\begin{array}{l}\text { Gingiva, lower lip } \\
\text { and the dorsum of } \\
\text { the tongue }\end{array}$ \\
\hline $\begin{array}{l}\text { Clinical } \\
\text { presentation }\end{array}$ & $\begin{array}{l}\text { Cauliflower or wart like } \\
\text { appearance }\end{array}$ & $\begin{array}{l}\text { White or red color, } \\
\text { papillary or roughed }\end{array}$ & $\begin{array}{l}\text { Painless papule } \\
\text { or nodule with } \\
\text { papillary projections } \\
\text { or plebby surface }\end{array}$ & $\begin{array}{l}\text { Multiple white to } \\
\text { pinkish papules }\end{array}$ & $\begin{array}{l}\text { Elevated, } \\
\text { pedunculated or } \\
\text { sessile vascular } \\
\text { mass with smooth, }\end{array}$ \\
\hline \multirow[t]{5}{*}{ Histopathology } & \multirow{5}{*}{$\begin{array}{l}\text { Finger-like projections } \\
\text { resembling } \\
\text { keratinized exophytic } \\
\text { verrucopapillary } \\
\text { processes, acanthosis, } \\
\text { and fibrovascular } \\
\text { stroma }\end{array}$} & \multirow[t]{5}{*}{$\begin{array}{l}\text { Stroma exhibits the } \\
\text { presence of foamy } \\
\text { histiocytes or granular } \\
\text { cells }\end{array}$} & $\begin{array}{l}\text { Fingerlike or } \\
\text { pointed projections } \\
\text { Chronic }\end{array}$ & $\begin{array}{l}\text { Hyperplastic } \\
\text { epithelium with } \\
\text { no keratosis }\end{array}$ & $\begin{array}{l}\text { lobulated or warty } \\
\text { surface } \\
\text { Thin and atrophic } \\
\text { epithelium }\end{array}$ \\
\hline & & & $\begin{array}{l}\text { inflammatory } \\
\text { infiltrate in }\end{array}$ & $\begin{array}{l}\text { Broadening } \\
\text { and clubbing }\end{array}$ & \\
\hline & & & $\begin{array}{l}\text { connective tissue } \\
\text { cores }\end{array}$ & $\begin{array}{l}\text { of the rete } \\
\text { ridges without } \\
\text { dysplastic }\end{array}$ & $\begin{array}{l}\text { Proliferating } \\
\text { of fibroblasts } \\
\text { and budding }\end{array}$ \\
\hline & & & $\begin{array}{l}\text { Produce "cupping } \\
\text { effect" }\end{array}$ & features & endothelial cells \\
\hline & & & $\begin{array}{l}\text { Presence of } \\
\text { mitosoid cell or } \\
\text { bodies } \\
\text { HPV }-2,4,6,40\end{array}$ & $\begin{array}{l}\text { Presence of } \\
\text { mitosoid cell }\end{array}$ & $\begin{array}{l}\text { Fibrinopurulent } \\
\text { membrane }\end{array}$ \\
\hline $\begin{array}{l}\text { Immuno- } \\
\text { histochemical } \\
\text { markers }\end{array}$ & p-16, HPV 6 and 11 & CD68 and Cathepsin B & $\begin{array}{l}\mathrm{P}-16, \mathrm{p} 53, \\
\text { Carcinoembryonic } \\
\text { antigen }\end{array}$ & HPV 13 and 32 & $\begin{array}{l}\text { ICAM-1, } \\
\text { VCAM-1, } \\
\text { CD-34 \& } \\
\text { CD-31 }\end{array}$ \\
\hline
\end{tabular}

Table 2: Differential diagnosis of verruca vulgaris

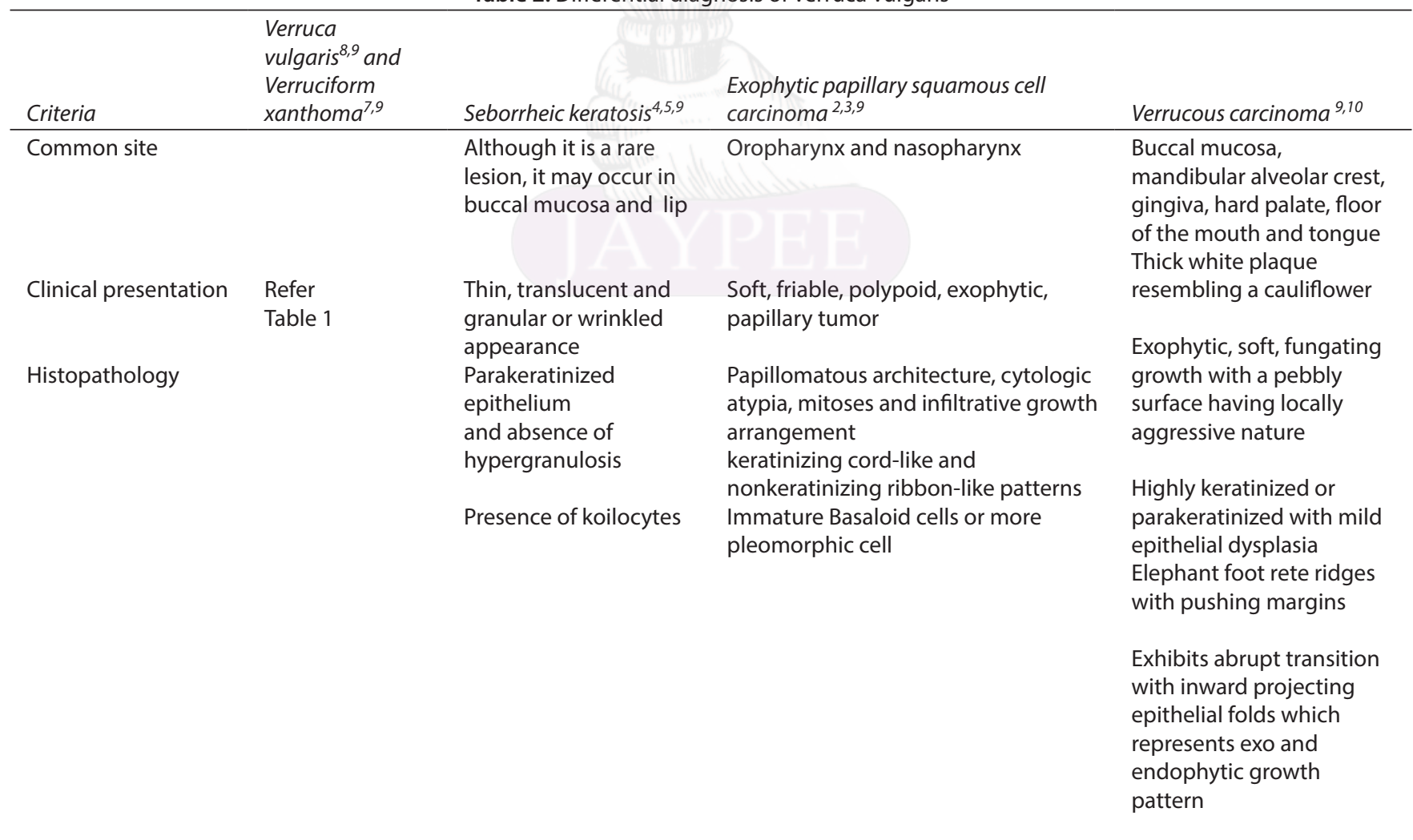




\begin{tabular}{|c|c|c|c|c|}
\hline Criteria & $\begin{array}{l}\text { Verruca } \\
\text { vulgaris, and } \\
\text { Verruciform } \\
\text { xanthoma }\end{array}$ & Seborrheic keratosis ${ }^{4,5,9}$ & $\begin{array}{l}\text { Exophytic papillary squamous cell } \\
\text { carcinoma }{ }^{2,3,9}\end{array}$ & Verrucous carcinoma $^{9,10}$ \\
\hline & $\begin{array}{l}\text { Refer } \\
\text { Table } 1\end{array}$ & - & $\begin{array}{l}\text { Ki-67, VEGF, MMP-2 and 9, } \\
\text { NQO1,CK-8, 13, } 18\end{array}$ & Cleft like spaces \\
\hline & & & & Parakeratin plugging \\
\hline & & & & $\begin{array}{l}\text { P53, E-cadherin and } \\
\text { MMP-1 }\end{array}$ \\
\hline
\end{tabular}

Table 3: Differential diagnosis of verruciform xanthoma

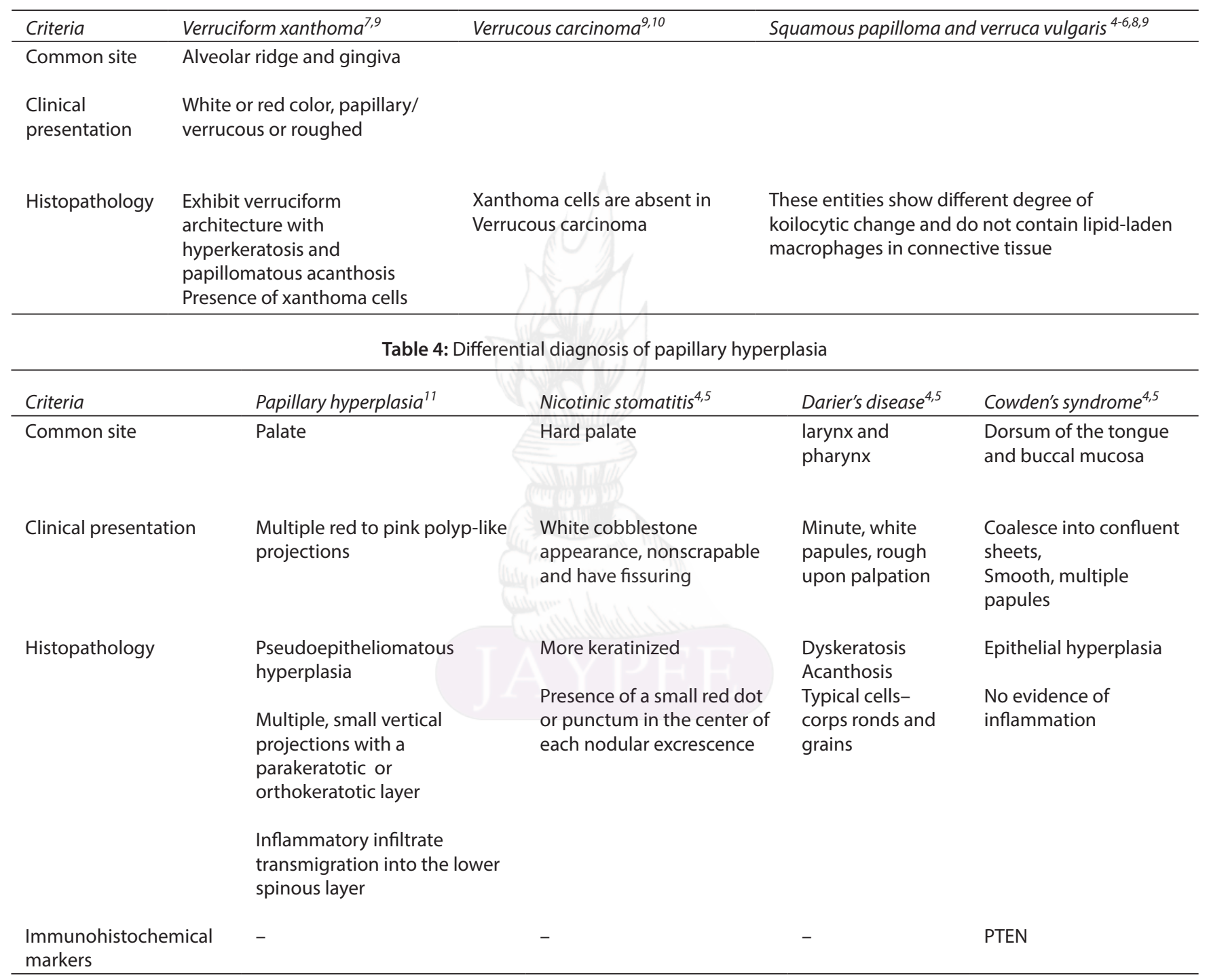

\section{Multifocal Verrucopapillary Lesions}

The common multifocal verrucopapillary lesions include papillary hyperplasia, verrucous carcinoma, papillary exophytic squamous cell carcinoma, focal epithelial hyperplasia, and verruciform leukoplakia.

\section{Papillary Hyperplasia}

Papillary hyperplasia is an unusual condition which is also represented as inflammatory papillary hyperplasia, papillomatosis, pseudoepitheliomatous hyperplasia, denture stomatitis. It is the painless and irreversible lesion most frequently involving the mucosa of the palate and lingual mandibular gingiva. It is always associated with the patients having ill-fitting dentures and poor oral hygiene (Table 4). ${ }^{11}$

\section{Focal Epithelial Hyperplasia}

Focal epithelial hyperplasia (FEH) is a benign contagious disease of the oral mucosa. It normally appears in childhood. It is also 
Table 5: Differential diagnosis of focal epithelial hyperplasia

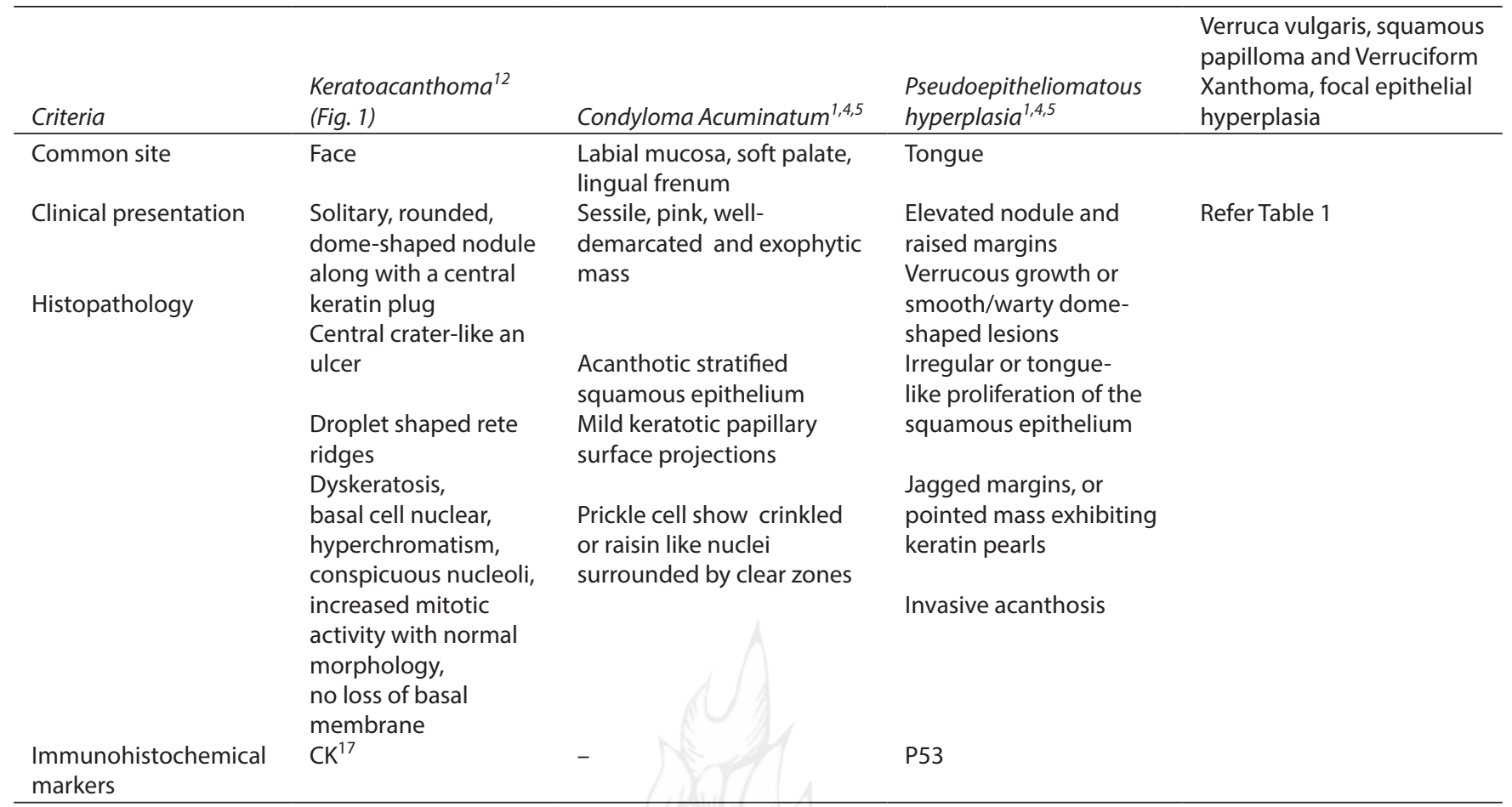

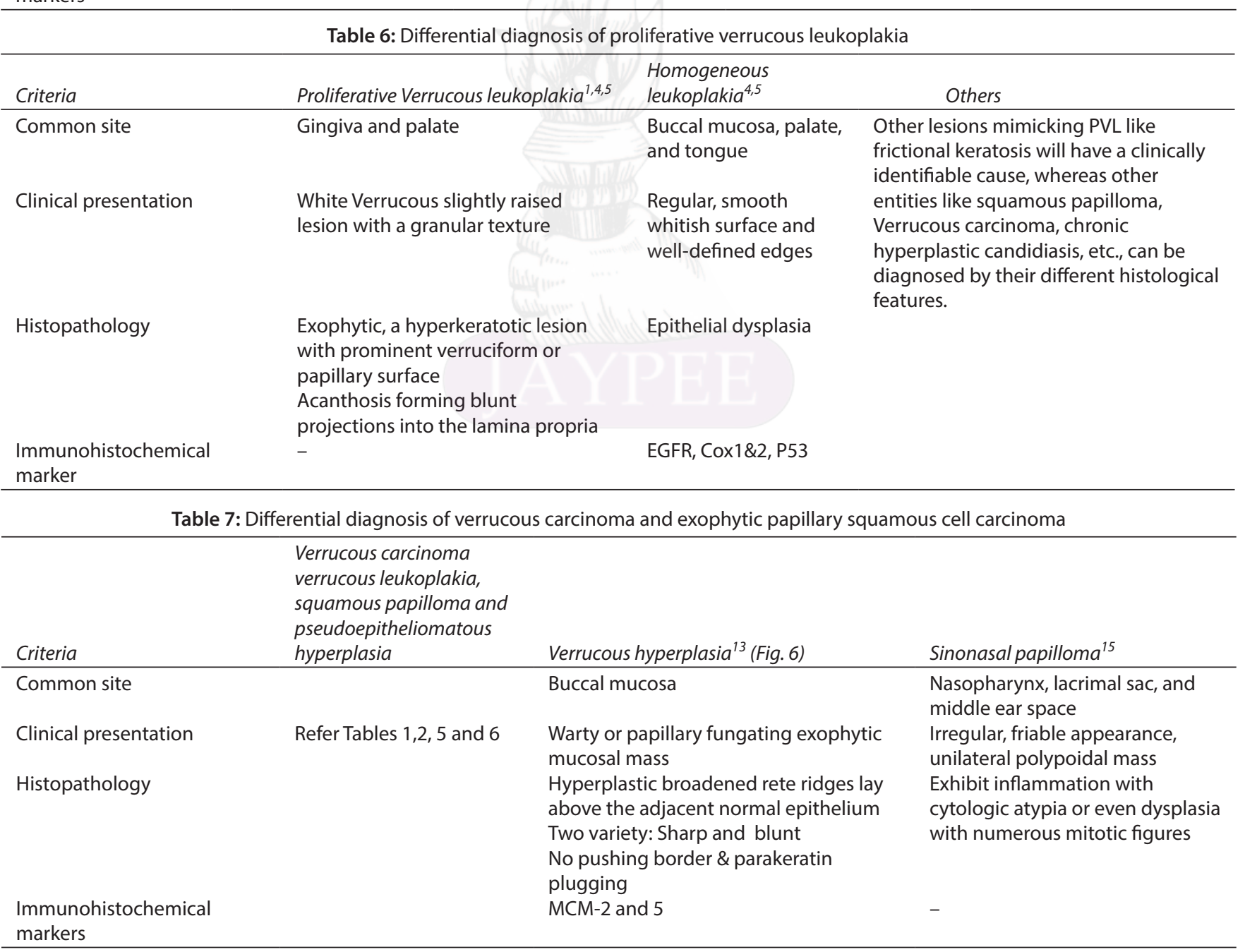




\section{Multifocal Verrucopapillary Lesions}

The common multifocal verrucopapillary lesions include papillary hyperplasia, verrucous carcinoma, papillary exophytic squamous cell carcinoma, focal epithelial hyperplasia, verruciform leukoplakia.

\section{Papillary Hyperplasia}

Papillary hyperplasia is an unusual condition which is also represented as inflammatory papillary hyperplasia, papillomatosis, pseudoepitheliomatous hyperplasia, denture stomatitis. It is the painless and irreversible lesion most frequently involving the mucosa of the palate and lingual mandibular gingiva. It is always associated with the patients having ill-fitting dentures and poor oral hygiene (Table 4). ${ }^{11}$

\section{Focal Epithelial Hyperplasia}

Focal epithelial hyperplasia (FEH) is a benign contagious disease of the oral mucosa. It normally appears in childhood. It is also termed as Heck's disease or multifocal papilloma.Various studies have reported that the condition remits spontaneously (Table 5).

\section{Proliferative Verrucous Leukoplakia or Verruciform Leukoplakia}

Proliferative verrucous leukoplakia (PVL) is an uncommon form of oral leukoplakia. It was first stated in 1985 by Hansen which develops initially as a white plaque of hyperkeratosis that eventually becomes a multifocal disease with confluent, exophytic and proliferative features. PVL shows specific characteristics, mainly a more aggressive biological behavior than other forms of leukoplakia. It is expressed by a tendency toward multifocality, a high probability of recurrence and a high rate of malignant transformation. It is defined as a continuum of oral epithelial disease with hyperkeratosis at one end of a clinical and microscopic spectrum and verrucous carcinoma or squamous cell carcinoma at the other (Table 6). ${ }^{4,5}$

\section{Verrucous Carcinoma and Exophytic Papillary Squamous Cell Carcinoma (Fig. 1)}

Oral verrucous carcinoma is a special form of well-differentiated squamous cell carcinoma. It was first described in 1948 by Lauren V Ackermann. Different names are used in the literature to describe this entity, including Ackerman's tumor, Buschke-Loewenstein tumor, florid oral papillomatosis, epithelioma cuniculatum, and carcinoma cuniculatum. It exhibits both exophytic and endophytic growth patterns (Table 7). ${ }^{3-5}$

The most common malignancy of the upper aerodigestive tract is squamous cell carcinoma (SCC). Crissman et al. proposed the term papillary carcinoma, and it is the rare variant of SCC. Currently, the WHO classification named this lesion as papillary SCC (PSCC). This is described in other parts of the body including skin, uterine, cervix, conjunctiva of the eye and thymus. In the upper aerodigestive tract, it occurs most commonly in the larynx. It is an apparent variant characterized by exophytic and papillary growth with a favorable prognosis. $3,4,5,14$

\section{Conclusion}

Verrucopapillary lesions of the oral cavity present a diagnostic dilemma because of similar clinical presentation. To achieve an accurate diagnosis, oral pathologists should have a sound knowledge about histopathology and biological behavior of these. This article features the unique characteristics of oral verrucopapillary lesions with respect to its intraoral location, clinical presentation, histopathology and specific Immunohistochemical markers that provide an aid for definitive diagnosis and treatment.

\section{References}

1. Vala D, Maiti SB, Ranjan R, et al. Verrucous papillary lesions of oral mucosa-a review. Journal of Advanced Medical and Dental Sciences Research. 2016;4(6):52-67.

2. Kapoor C, Dhanpal R, Shetty C, et al. Verruco-papillary lesions in relation to human papilloma virus. Journal of cancer research and therapeutics 2013;9(3):541-542.

3. Thomas GJ, Barrett AW. Papillary and verrucous lesions of the oral mucosa.Diagnostic Histopathology 2009;15(6):279-285.

4. Regezi JA, Sciubba JJ, Jordan RC. Oral pathology: clinical pathologic correlations. 6th ed.Elsevier Health Sciences 2016 Feb 25.

5. Neville BW, Damm DD, Chi AC, et al. Oral and maxillofacial pathology.3rd ed. Elsevier Health Sciences; 2015.

6. Jaju PP, Suvarna PV, Desai RS. Squamous papilloma: case report and review of literature. International Journal of Oral Science 2010;2(4):222-225.

7. Hegde U, Doddawad VG, Sreeshyla HS, et al. Verruciform xanthoma: A view on the concepts of its etiopathogenesis. Journal of oral and maxillofacial pathology: JOMFP 2013;17(3):392-396.

8. Ural A, Arslan S, Ersöz Ş, et al. Verruca vulgaris of the tongue: a case report with literature review. Bosnian Journal of Basic Medical Sciences 2014;14(3):136-138.

9. Mehrotra D, Goel M, Kumar S, et al. Oral verrucous lesions: Controversies in diagnosis and management. Journal of Oral Biology and Craniofacial Research 2012;2(3):163-169.

10. Santoro A, Pannone G, Contaldo $M$, et al. A troubling diagnosis of verrucous squamous cell carcinoma ("the bad kind" of keratosis) and the need of clinical and pathological correlations: a review of the literature with a case report. Journal of Skin Cancer 2011;2011.

11. Lambson GO. Papillary hyperplasia of the palate. The Journal of Prosthetic Dentistry 1966;16(4):636-645.

12. Kwiek B, Schwartz RA. Keratoacanthoma (KA): An update and review. Journal of the American Academy of Dermatology. 2016 Jun 1;74(6): 1220-1233.

13. Zain RB, Kallarakkal TG, Ramanathan A, Kim J, Tilakaratne WM, Takata T, Warnakulasuriya S, Hazarey VK, Rich A, Hussaini HM, Jalil A. Exophytic Verrucous Hyperplasia of the Oral CavityApplication of Standardized Criteria for Diagnosis from a Consensus Report. Asian Pacific Journal of Cancer Prevention 2016;17(9) 4491-4501.

14. Fitzpatrick SG, Neuman AN, Cohen DM, et al. Papillary variant of squamous cell carcinoma arising on the gingiva: 61 cases reported from within a larger series of gingival squamous cell carcinoma. Head and Neck Pathology 2013;7(4):320-326.

15. Fooanant S, Pattarasakulchai T, Tananuvat R, et al. Sinonasal papilloma in chiangmai university hospital. J Med Assoc Thai 2013;96(3):329-333. 